UDC $622.026 .7-33$

\title{
石炭の切削機構についで
}

$\begin{array}{ccccc}\text { 正会員 会 田 俊 } & \text { 夫** }^{* *} \\ \text { 正会員 岡 } & \text { 本 } & & \text { 隆 }\end{array}$

\section{On the Cutting Mechanism of Coal}

Toshio AIDA and Takashi OKAMOTO

In this paper, the authors studied on the cutting mechanism of brittle materials as gypsum, cement, rock and coal blocks.

Results obtained from these experiments are as follows:

1. Type of cutting mechanism changes from shear type to crack type as depth of cut and brittle index (ratio of compressive and tensile strength of material defined by the authors) increases, with larger fluctuations in cutting resistance.

2. Fluctuation in cutting resistance decreases as bit width increases.

3. Distance of peaks of cutting resistance increases as rake angle of bit decreases.

4. Cutting resistance of brittle materials in practical cutting conditions may be concluded as the press-in resistance of cutting edge.

5. When cutting brittle materials, tensile stress in the case of larger rake angle bit and shear stress in the case of smaller rake angle bit, takes the most important role in cutting breakage occurance.

\section{1. 緒、言}

従来金属切削に拉ける機構学的研究は多くの研究者に よつてなされ，その切削機構については流れ型，せん断 型などの特色が明らかにされている。石宸の切削に対し ては従来より筆者らは多くの研究を行い, それらの結果 については順次報告してきた。そしてこれらのうち切削 現象の本質である切削機構については，それが亀裂型で あり，したがつて刃物にかかる切削抵抗は被削材料中へ の刃物の進入に伴弓押込抵抗であることを述べ，刃先付 近の空力分布を光弾性実験により調べた結果を一部報告 しだ1。しかしながら石炭の切削機構としての上述べ た魹裂型は一般の切込深さの場合であつて，切込が極め て小さくなると切削形態が変るように見うけられるの で，簕者らはこの際石炭のみならず，いわゆる脆情材料 の切削㙨構を広く䘽察した結果, 切削の形態が被削材料 の脆さの度合によつて相当に変化することを認めたの でここにとりまとめて述べることにする。

\section{2. 切削機構の一般的説明}

第 1 圀は軟鋼および普通錈鉄の切削機構を示したるの で, (a)の軟鋼では滑りの間隔が極めて短く, 切削首は

* 昭和 34 年 7 月 6 日炏理 昭和 34 年度日本鉱業会春季大会にて講演

** 工博, 京都大学教授, 釯山学教室

*** 京都大学助手 鉱山学教室
流れていわゆる流れ型 (Flow type) の切削機構を示し ている。この場合の破壊はせん断応力によつて滑りが発 生するもので, その切削抵抗は多くの研究者淂っつて解 析されている2)。この滑りの間隔は極めて小さく, 連続 的であるので，切削抵抗の変動は第 1 図のように極めて 少ない。

ところが鋳鉄では軹鋼よりも脆い材料であるので，切 削の機構も異なつたものになつてくる。脆さの度合を表 わすのにここでは一応圧縮強さ $S_{c}$ と引張強さ $S_{t}$ との 比をもつて表わすことにした。すなわち

脆性度 $B_{r}=\frac{S_{c}}{S_{t}}$

(a) 乾鋁の切削

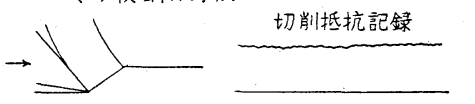

(b) 鋳鉄の切削

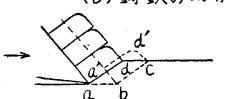

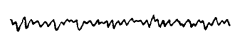

$\mathrm{Br}_{r}=3 \sim 4$

(C) セメント材の切削

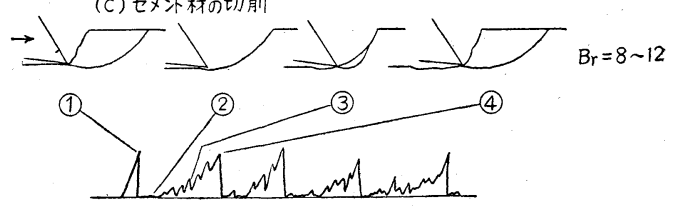

第1図 各種材料の切削機棈 
(1) 流水型 (Flow type)

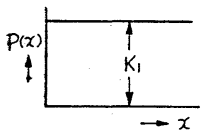

(2) 世九断型 (Shear type)

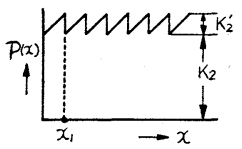

(3) 重裂型 (Crack type)

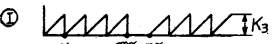

(11)
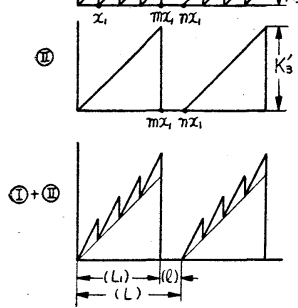

第 2 図流れ型, せん断

型, 亀裂型の切削模型
$S_{c} ， S_{t}$ がそれぞれ異な つた寸法効果を示す場合は 試験寸法の大小により $\mathrm{Br}$ の值も異なつてくるが，こ こでは一応試験片の大きさ は直径 $30 \mathrm{~mm}$, 高さ $55 \mathrm{~mm}$ 程度のものについて示し た。

この定義よりすれば前述 の軟鋼では第 1 図に添記し たように $B_{r} \cong 1$ であり，普 通鋳鉄では $B_{r}=3 \sim 4$ とい う值をとる。このような脆 性金属になると滑りの間隔 が幾分大きくなり，第1図 に示すように刃物の進行に 伴い, abcd の部分は $\mathrm{a}^{\prime} \mathrm{bc}$ $\mathrm{d}^{\prime}$ に圧縮され，b c 面に沿 つて 滑りを起すので, 切削 抵抗の変動も大きく，いわゆるせん断型 (Shear type) の切削機構を示す。

金属以外の脆性材粼，たとえばセメント材を例にとる と, 脆性度 $B_{r}$ は 8〜12 と大さくなり，このような材料 では塑性变形が極めて少なく, 第 1 図(c) の上うに物 の王入により亀裂を生ずるととの集展にはほとんどェネ ルギを必要とせず，破壊は急激に進んで切削抵抗は 0 に なり，ついで小さい龟裂を繰返しながら再び大亀裂を生 じ,これを繰返していくので, 切削抵抗の変動も図に示 すように極めて著しくなり, 亀裂型 (Crack type) の切 削機構となる。

これらの切削形式の抵抗変化を模型的に第 2 圀のよう に示してみた。脆性度 $B_{r}=1$ である軟鋼などが示す流 れ型機構では前述のように切削抵抗の変動が法とんどな く，切削抵抗 $P(x)$ は時間 $x$ に臂せずほぼ一定として

$$
P(x)=K_{1}
$$

の直線で表わす。この $K_{1}$ は切込深さ，被削材料のせん 断強さなどに比例する。この場合の切削抵抗の最大值 $P$ と平均值 $p$ との比，すなわち变動比 $r_{p}$ は

$$
r_{p}=\frac{P}{p}=1
$$

である。

热ん断型の機構では切削抵抗の变化は模型的にフーリ エの級数の形で表わすことができる。すなわり

$$
P(x)=K_{2}+\frac{K_{2}^{\prime}}{\pi}\left(\pi-2 \sum_{k=0}^{\infty} \frac{\sin k \frac{\pi}{x_{1}} x}{k}\right) \cdots
$$

ここで $x$ は滑りの間隔であり, 常教 $\left(K_{2}+K_{2}^{\prime}\right)$ は前同様
被削材料のせん断強さあるいは圧縮強さに比例するもの である。この場合の変動比は

$$
r_{p}=\frac{K_{2}+K_{2}^{\prime}}{K_{2}+\frac{K_{2}^{\prime}}{2}}
$$

つぎに筆者が詨象とする石炭や岩石あるいはセメント 材のよ 5 に脆性度 $B_{r}$ が大きい材料に扔いては切込があ る程度以上大きくなると亀裂型の様相を呈するが，この 場合は第1図に示したように小刍裂拉よび大亀裂と繰返 しを緢けるので，模型的には第2四 (3)に拉いて(I) (II) を合成して切削抵抗の変化を考えることができる。すな わら小亀裂を繰返して時間 $m x_{1}$ に大亀裂を生じ， $n x_{1}$ ま で切削抵抗は 0 で，ついで再び小亀裂を繰返すことを存 えれば

$$
\begin{aligned}
& x=0 \sim m x_{1} \\
& P(x)=\frac{K_{3}}{\pi}\left(\pi-2 \sum_{k=0}^{\infty} \frac{\sin k \frac{\pi}{x_{1}} x}{k}\right)+ \\
& \frac{K_{3}^{\prime}}{\pi}\left(\pi-2 \sum_{k=0}^{\operatorname{csin} k \frac{\pi}{m x_{1}} x} \frac{k}{k}\right) \\
& x=m x_{1} \sim n x_{1} \\
& P(x)=0 \\
& r_{p}=\frac{2 L}{L_{1}}
\end{aligned}
$$

ここで $K_{3}+K_{3}{ }^{\prime}=P$ (切削抵抗の最大值) は均質な材 料ではとの強さに比例する3。。をた $L, L_{1}$ は切削長さに

\begin{tabular}{|c|c|c|c|c|c|}
\hline $\begin{array}{ll}\text { 䪤 } & \text { 驗 } \\
\end{array}$ & $\begin{array}{c}\text { 模型による } \\
r p\end{array}$ & $\begin{array}{c}\text { 実湘による } \\
r_{p}\end{array}$ & $\begin{array}{l}\text { 実 験 } \\
\text { 番 号 } \\
\end{array}$ & $\begin{array}{c}\text { 模型による } \\
r p\end{array}$ & $\begin{array}{c}\text { 実測による } \\
r_{p}\end{array}$ \\
\hline $\begin{array}{l}1 \\
2 \\
3 \\
4\end{array}$ & $\begin{array}{l}2.84 \\
3.66 \\
2.77 \\
2.92\end{array}$ & $\begin{array}{l}3.61 \\
5.31 \\
4.27 \\
4.52\end{array}$ & $\begin{array}{l}5 \\
6 \\
7\end{array}$ & $\begin{array}{l}2.56 \\
2.30 \\
3.40\end{array}$ & $\begin{array}{l}3.76 \\
3.74 \\
5.96\end{array}$ \\
\hline
\end{tabular}
とつたが：この模型による場合，いわゆる切削中の对物 の遊び $し$ がなければ $\left(L=L_{1}\right)$ 変動比 $r_{p}$ は 2 である。し かしながら切込深さが大きくなると物の遊びも大にな り（7）式により $r_{p}$ は 2 よりさくなるが，実際の切削 に执いて測定した $r_{p}$ は模型の式より求めたものよりは いくらか大きい值を示す。第 1 表は (7) 式により $L, L_{1}$ を測つて求めた模型的な变動比と実測変動比の比較であ る。

第 1 表 切削抵抗変動比の比較

\section{3. 石炭の切削機構}

$3 \cdot 1$ 脆性度 $\boldsymbol{B}_{r}$ が相異する場合の切削破壊の様相 石炭の切削機構を観察するのと同時汇均質脆性体とし て, 石高, セメント材についても実験を行つた。これら の試料の要目は第 2 表のようである。

上述のように一般に脆性材料の切削形式は龟裂型と又 
第 2 表切削試料要目

\begin{tabular}{c|c|c|c}
\hline & E縮強さ $S_{c}$ & 引張強さ $S_{t}$ & $B_{r}=S_{c} / S_{t}$ \\
\hline 石高 (湿) & $30.5 \mathrm{~kg} / \mathrm{cm}^{2}$ & $6.5 \mathrm{~kg} / \mathrm{cm}^{2}$ & 4.7 \\
ゼメン乾) & 93.4 & 18.4 & 5.1 \\
\hline
\end{tabular}
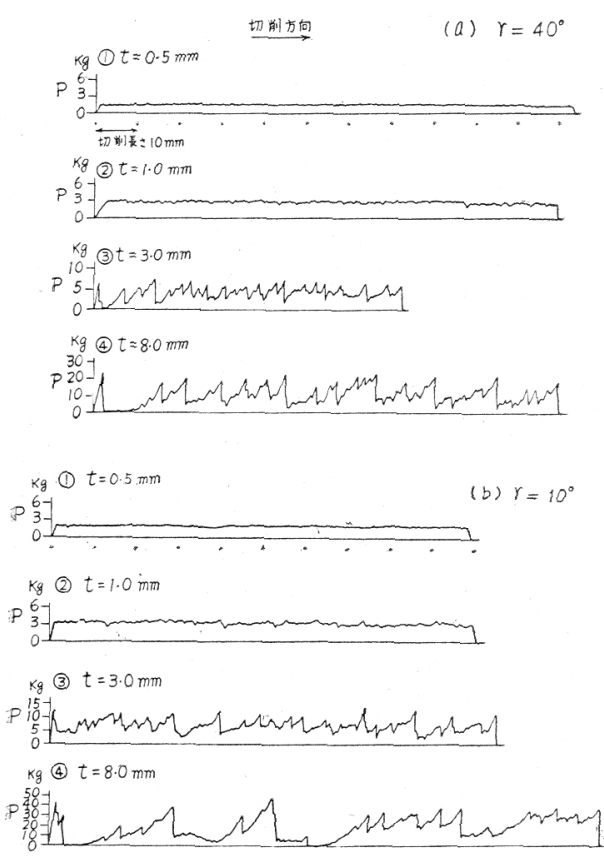

第3 図 石亮（湿）の切削抵抗オッシログラフ

られるがここ机はコール・カッタ・ピックなどで通常の 大きい切达深さの場合で西つて，これのみで終始するの でないことが認められる。第 3 図は石育（湿）の刃幅 $B$ $=15 \mathrm{~mm}$ のピック・バイトによる切削抵抗のオッシログ

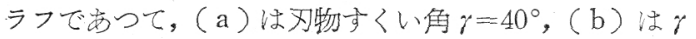
$=10^{\circ}$ の場合である。(1)は切达深さ $t=0.5 \mathrm{~mm}$ の場合で

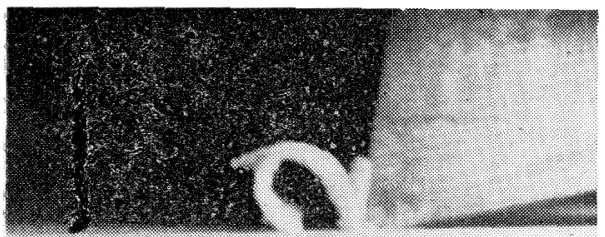

世(1)石管 (湿) $r=10^{\circ}$ $t=0.5 \mathrm{~mm}$

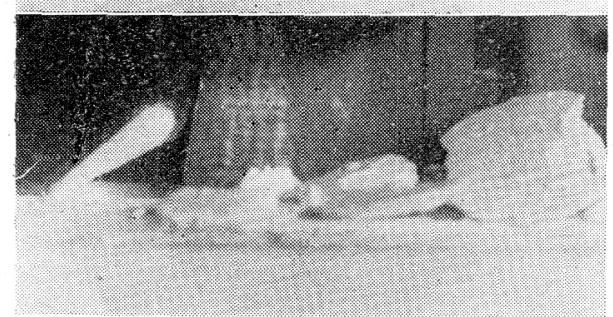

$$
\begin{aligned}
& \text { 世3)石高(湿) } \\
& r=10^{\circ} \\
& t=8.0 \mathrm{~mm} \\
& \text { (4) ๖ンント材 } \rightarrow \\
& r=40^{\circ} \\
& t=8.0 \mathrm{~mm}
\end{aligned}
$$

(2)石育 (湿) $\rightarrow$ $y=10^{\circ}$ $t=1.0 \mathrm{~mm}$

西つて第4 图の切削写真(1)で判る上万波被材の分離の

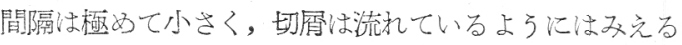
が，せ九断型の機構である。この場合の切削抵抗の変期 は極めて小さく定常的な切削がうづいている。(2は汤込 深さ” $t=1 \mathrm{~mm}$ の場合であつてせん断型の䇐相をはつきり と示し（第4罒(2)，(3)，(4) と順次切込が大きくなると，

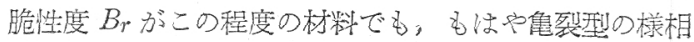
を示し(第4 図 (3))，切削抵抗の变動比 $r_{p}$ b第 7 図沉之

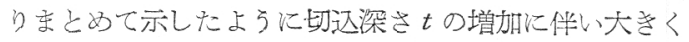
なつてくる。な技この場合切削速度は $v=484 \mathrm{~mm} / \mathrm{min} て ゙$ 実験を行つたが，v=63mm/min の低速でも大きい差は 認奶られなからた。

つぎに石膏 (乾) の $B_{r}=5.1$ と少し大さい村粼で浊上 に比較して変動比も第 7 図化示すように幾分大きくな る。この場合のオッシログラフは省略したが，つぎに $B$ $=9.1$ のセメント材について観察すると上の場合汇比し て著しい差を沶てくる。この場合の切削抵抗のオッシ ログラフ第 5 図に示したが， $t=0.5 \mathrm{~mm}$ 々極めて小さ い場合でも同図(1)示すように切削提抗の変動も西る程 度大さくなり，せ九断型の様相が判然とし，t=1 mm で 早人も龟裂型の様相が久克, $t=3 \mathrm{~mm}$ 程度では上述のも のに比へてはるが判然とした切削形態である。かつ脆 性度 $B_{r}$ がこの上うに大きいと変動比 $r_{p}$ 㺫順次大きく

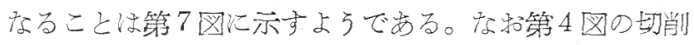
写真(4)恃典型的な龟裂型切削で，会の実際の切削抵抗の

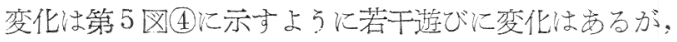
さき汇示した切削模型と類似した形索とつていることが 判る。

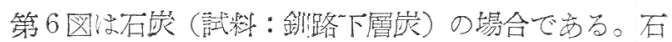
炭の場合依 $B_{r}$ が 25 程度で西つて脆性度はい上い上大 き々, したがつて切削抵抗の变動も大きく，から不均質 性む加わつてセメント材のような画一的なるのにならな
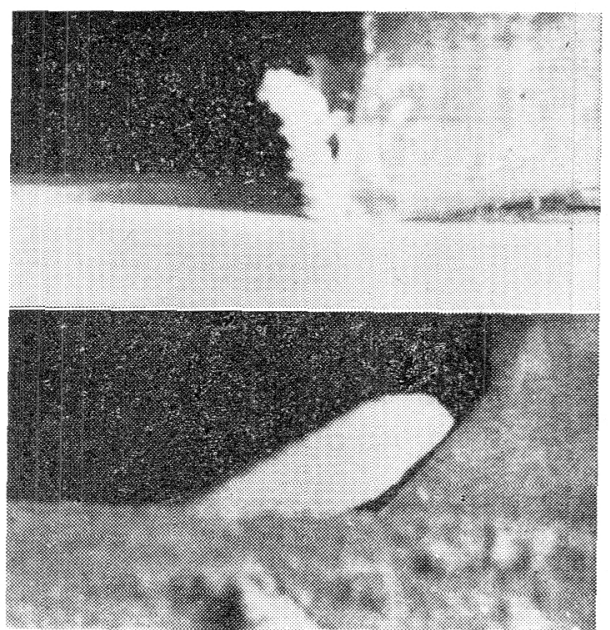

切削写真 


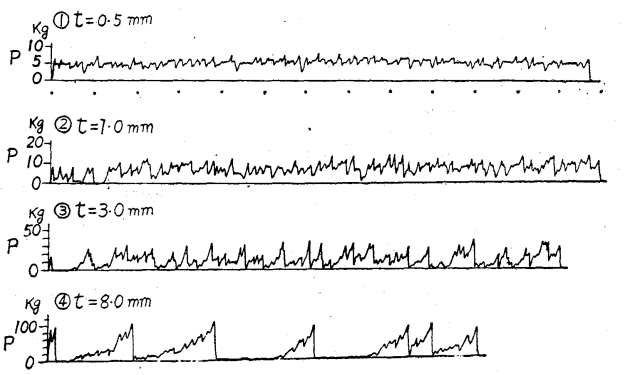

第 5 図セメント材の切削抵抗オッシログラフ $\left(r=40^{\circ}\right)$

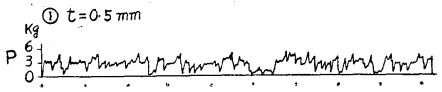

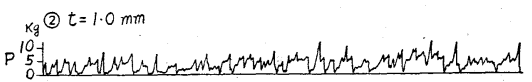

$\mathrm{kg}$ (3) $t=4.0 \mathrm{~mm}$

年

$\mathrm{kg}(4) \mathrm{t}=8.0 \mathrm{~mm}$

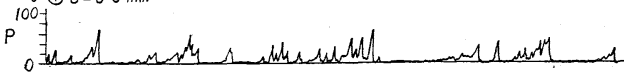

第 6 図 石炭の切削抵抗オツシログラフ $\left(r=40^{\circ}\right)$

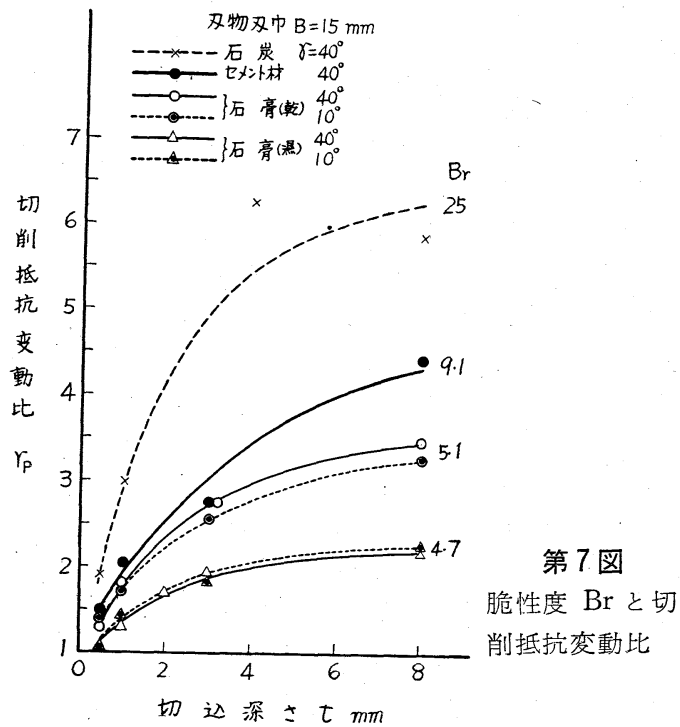

いで不規則な形になる。同図の(1) $t=0.5 \mathrm{~mm}$ の場合で あつて，早くもせん断型と亀裂型が相半ばしているよう な様子が考光られ，以下(2) $t=1 \mathrm{~mm}$ では亀裂型切削の 様相が示され，(3)，(4)と切込深さが大きくなるにしたが つて切削抵抗の変動が著しくなつてくる。これらの変化 の樣子も第7図に併せ示してある。

以上のことから切削形態は材料の脆性度 $B_{r}$ によつて 著しく左右され，Br が大さいほど，また切込深さ $t$ が 大きい汪ど切削抵抗の変動が著しくあらわれることにな

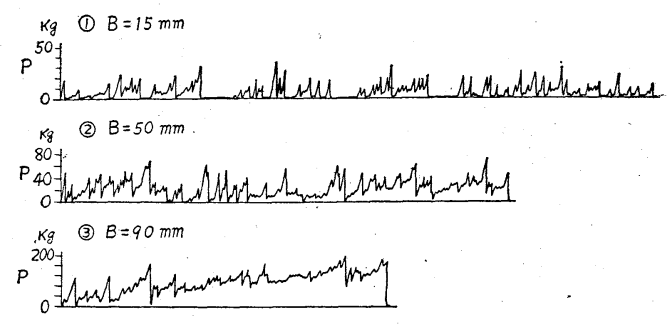

第 8 図刃物刃幅の変化による切削抵抗の相異 $\left(r=40^{\circ}, t=4 \mathrm{~mm}\right)$

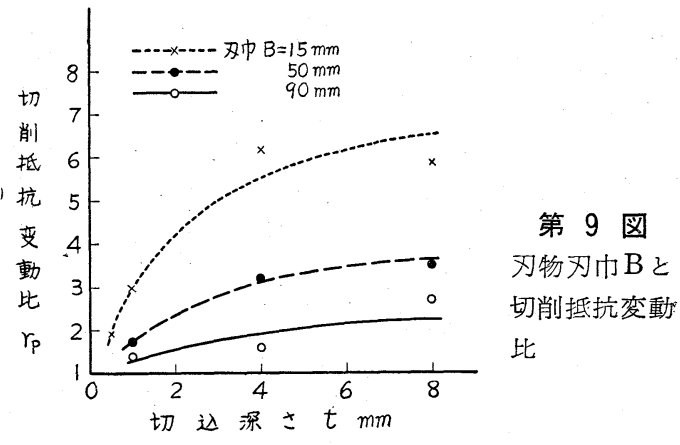

る。

\section{$3 \cdot 2$ 刃物刃幅による切削形態の相異}

筆者らの石炭切削害験ではすべて実際の切削と同じょ うに三次元切削を行つているが，同一の断込深さに颃い ても羽物の刃幅が大きくなると石炭の、刚幅方简の不均質 性のため, 切削に拈いて一つの貝がら状の破面を形成せ ず，すなわち邓幅全部にわたつて同時に切削破壊が行わ れずに刃幅方向に細かく破壊される。第 8 园は切込深さ を一定にして刃幅 $B$ を変えて石炭を切削した場合の切削 抵抗オッシログラフの 1 例で，刃幅が犬さくなるにした がい変動は小さくなつてくることが判る。(第 9 図)

な打刃幅が小さくても切込深さが極めて小さいとこの 傾向になることが観察される。

\section{3 切削速度による差異}

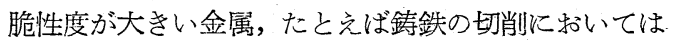
実用の切込深さおよび切削速度の範囲ではせん断型の機 構であるが，切削速度が $3.6 \mathrm{~mm} / \mathrm{min}$ と極めて低速にな ると亀裂型の切削機構となり，それとともに滑りの間隔 も大きくなることが認められている4。

このように同一包削条件下に捈ける滑り (破壊) の間 隔，すなわち切粉の大きさにより切削機構の变化を推定 することができる。石炭やセメント材については切削抵 抗技よび切粉の大ささが切削速度によつてほとんど変化 のないことから，切削の機構も速度によつて変らないも のとみてよい。この点についての詳細は別の機会に改め て述べることにする。 


\section{$3 \cdot 4$ 刃物すくい角による相異}

刃物すくい角子が小さくなると後述するように主とし て刃物の压入に伴い刃先付近溌生するせ几断広力に上 ク，rが大きくなつて用先が鋭くなると主として引張応 力により材料は破壊 (切削) されるが，この種の脆性材 料では $\gamma$ が小さとせん断による滑り（破壊面）が遠く まで進展する傾向になる。この傾向は鉡鉄のせん断型切

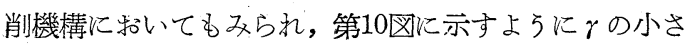
い添ど滑りの間隔は大きくなつている。第11図は大理石

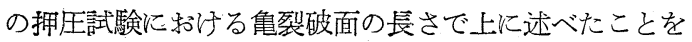
示している。乙たがつて実際の切削に招いてもこの傾向 はあらわれ，第 3 図 (a) ( b ) 亿示す切削抵抗才ッシ口 グラフからも判るように，大亀裂の間隔生すくい角の小 さいほど大きくなつている。

\section{5 急裂破面の大きさと切削抵抗}

石炭や岩石などの龟裂型切削に拉いては次に簡単に述 べるように金属切削に括けるような滑り面の世九断抵抗 ではなく，刃物の押込抵抗であることが考党られる。し たがつてこの種の刍裂型譏構に执いては切达深さの大小 によつてはく離される切粉の大きさは当然変化するが， これと切削抵抗 $P$ とが比例しない。すなわち金属切削に おける

$$
P \propto A \tau_{s}
$$

の概念が成立しないことである。ここに $A$ 惯り面の面 積， $\tau_{s}$ 注被削材料のせ几断強さである。第 12 図は $t=1.0$ $\mathrm{mm}$ の切込深さの場合の切削抵抗を基淮にして他の場合 の破面面積比扔よび切削抵抗比の関係を示したものであ る。もしも(8)式の関保があるならば, これらの実験值 は困の破線上に集るべきである。せん断型に近くなる脆 性度 $B_{r}$ の低い材料ではそのようにみられるが，典型的 な龟裂型切削になる $B_{r}$ の大きい材料では雲とんど变倚 して扮り，切削抵抗が破面の面積に比例しないことを示 している。

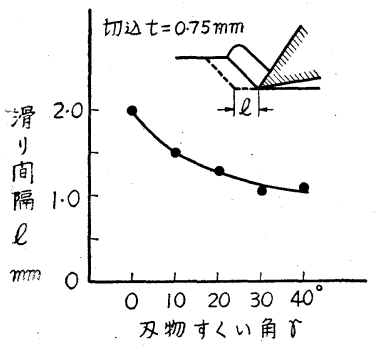

第10図鋳鉄の切削に拕ける 滑りの間隔

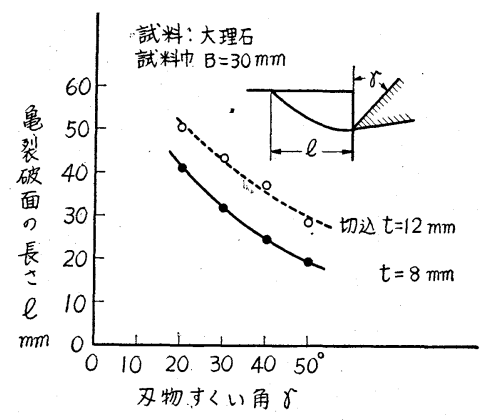

第 11 図大理石の押圧試験に扝け る破面の長さ

\section{4. 刃物圧入時の解析}

さきに述べたよに脆性材料の嶑裂型の切削形態に抒 いては，邓物の圧入により龟裂を生ずるとその進展にば ほとんどェネルギを必夏とせず急激汇切削片がはく離す るので, 前項に示したように切削抵抗は破面のせん断抵 抗ではなく，网物の押込抵抗であると考学られる。この

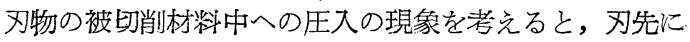
摩耗のない場合，第 13 図に扮いて切削幅を $B$ ，圧入深さ を $h$ ，単位面積当りの材料の抗厌力を $n$, 刃面と材料の 間の見掛けの摩擦係数を $\mu$ として計算すれば，主切削抵 抗 $P$ 扰よび背分力 $R$ は二次元的に

$$
\begin{aligned}
& P=n h B(\cot \gamma+\mu) \\
& R=n h B(\mu \cot \gamma-1)
\end{aligned}
$$

となるわ。すなわち圧入深さの増加とともに切削抵抗は 直線的に増加し，ついにある一定深さに達したところで 材料の邓先近くが破壊限界応力に達し破断することにな る。このことは実験的にも確めている。これらの実験結 果をるとにして材料の抗圧力 $n$ を求めるとこれは押込硬 度 $H$ と関連性を示し，炭理の発達の極めて少ない石孷や あるいは均質なセメント材に招いて切削抵抗が押込硬度 に比例することと音一致している。

さてこのよ5に刃先の圧入により切削抵抗が漸次増加 し，材料内の生起応力む堌加してついに破断を起寸わけ であるが，この刃先の圧入による材料内部の応力の状態 を二次元光弾性実験上り求めて第14四伙示した。これは 刃先を通る水平線上の応力分布を示したもので，すくい 角 $\gamma=0$ の場合は引張である $\sigma_{x}$ よりるせん断応力 $\tau_{x y}$ が 大きいが，rが大きくなるにつれ $\sigma_{x}$ が順次大きくなつ てくる。ここで脆性材料のせん断強さ $\tau_{s}$ をモールの応

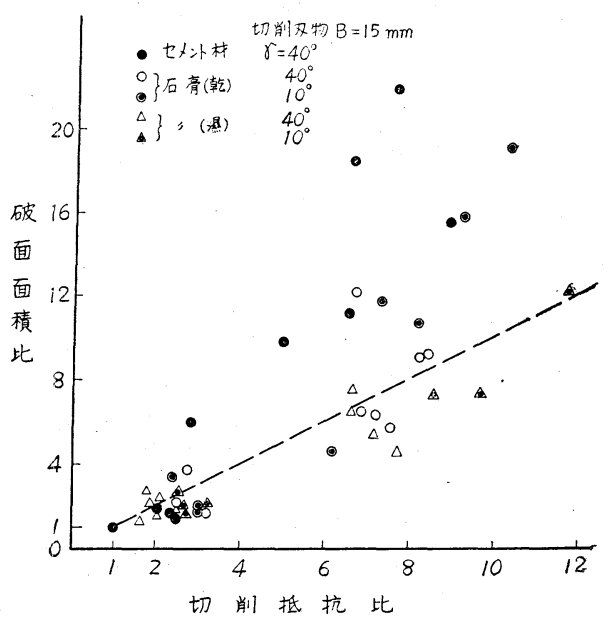

第 12 図 破面面積比々切削抵抗比 


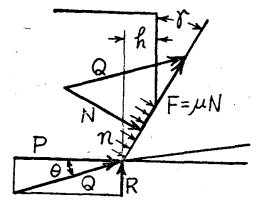

第 13 図被削材料中 への刃先の圧入

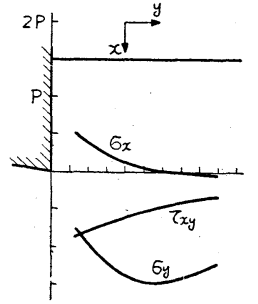

(i) $\gamma=0^{\circ}$

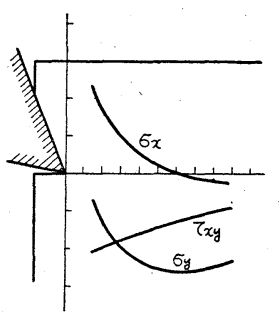

(ii) $\gamma=20^{\circ}$

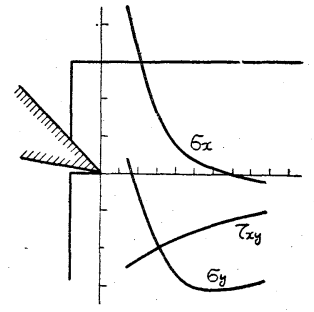

(iii) $\gamma=40^{\circ}$

第14図为先線上の応力分布

力円の包絡線を直線に扣きかえることにより

$$
\tau_{s}=-\frac{S_{t} S_{c}}{S_{t}-S_{c}}
$$

として，石炭に対し $S_{c} \cong-25 S_{t}$ として計算すれば

$$
\tau_{s}: S_{t}: S_{c} \cong 0.96: 1: 25
$$

となり，これらの比より判るようにすくい角が小さいと 刃先の圧入により生ずるせん断庆力による破壊であり， $\gamma=40^{\circ}$ では完全な引張破壊であり, そして $\gamma=20^{\circ}$ 程度 がその中間であることが推察される。

\section{5. 結言}

以上に石炭の切削形態について二，三考察した結果を 述べた。すなわち一般に脆泩䊷料の切削機構は亀裂型と 認められるのであるが，切込深さが極めて小さくなると せん断型の様相を呈することを明らかにし，かつ材料の 脆さの度合を表わすのに脆性度 $B_{r}$ を定義し，これと切 削形態あるいは切削抵抗の変動比などとの関連性を明ら かにした。また刃幅や对物の角度, 切削速度などの要素 との関係についても同椂に検討した。

さらに脆性材焠の切削抵抗は刃物の押込抵抗であるこ
とを示し，同時に刃物の圧入に伴ら被削材料内の生起底 力を二次元光弾性実験により解析し, 对物のすくい角が 小さいときはせん断応力により，すくい角が大きくなつ て刃物が鋭くなると引張応力によつて破壊されるもので あることを考察した。

な执これらの解析は刃物の刃先に摩耗のない場合であ つて, 刃先が摩耗した場合の考察は改めて述べることに したい。

本研究の一部は昭和33年度科学試験研究費補助金によ り行つたものである。

\section{文献}

1) 会田俊夫・岡本隆：切削採炭機械化関する基碟的研究，日本機械学会 誌, 第61巻, 第472号 (昭和33年 5 月) p. 522 。

2) た充ば, M. Field and M. E. Merchant: Mechanics of Formation of the Discontinuous Chip in Metal Cutting Trans. A.S.M.E. July. 1949, p. 421 .

M. E. Merchant : Basic Mechanics of the Metal Cutting Process Journal of App. Mech. Sep. 1944, p. 168.

3) 三雲英之助・会田俊夫・岡本隆 : 石炭の強度と切削抵抗, 日本鉣業会 誌, 第73巻, 第824号 (昭和 32 年 2 月) p. 81 .

4) 大越諒: 切削抵抗化関する研究, 理研畐報, 第12巻,第 1 号, p. 71 .

5) 三雲英之助・会田俊夫・网本 隆 : 石炭の切削抵抗と硬さとの関連性 飞つWて (II), 日本釷業会誌, 第70巻, 第793号 (昭和 29 年 7月) p. 291 . 